\title{
The basophil activation test reflects the severity and the threshold of allergic reactions to peanut - a double-blind-placebo-controlled peanut challenge study
}

Alexandra Santos*, Abdel Douiri, Alick Stephens, Suzana Radulovic, George du Toit, Victor Turcanu, Gideon Lack

From Food Allergy and Anaphylaxis Meeting 2014

Dublin, Ireland. 9-11 October 2014

\section{Background}

Peanut allergic patients may react to small amounts of the allergen with symptoms that can be life-threatening. The management of peanut allergy (PA) relies on allergen avoidance and adrenaline auto-injector for rescue treatment in cases at risk of anaphylaxis. Biomarkers of severity and threshold could improve the management of PA.

\section{Objective}

To assess the utility of the basophil activation test (BAT) to predict the severity and the threshold of reactivity to peanut on double-blind-placebo-controlled-peanut-challenges (DBPCPC).

\section{Methods}

Patients with positive DBPCPC were included in the study. The severity of the allergic reaction on DBPCPC was scored and the threshold dose was determined. Skin prick test, specific IgE to peanut and its components and $\mathrm{BAT}$ to peanut extract $(\mathrm{PE})$ were performed on the day of the challenge.

\section{Results}

44 peanut allergic children (median age 5 years) reacted to peanut on DBPCPC with clinical symptoms than ranged from oral allergy syndrome to anaphylaxis. $61 \%$ of patients reacted to $0.1 \mathrm{~g}$ of peanut protein. The mean \%CD63+ basophil at 10 and $100 \mathrm{ng} / \mathrm{ml}$ of PE was independently associated with severity $(\mathrm{p}=0.012)$ whilst $\mathrm{CD}$-sens (1/EC50x100) was independently associated with threshold $(p=0.039)$ of allergic reactions to peanut. Severity and

King's College London, London, United Kingdom threshold parameters were correlated both at the clinical $(\mathrm{Rs}=-0.38 ; \mathrm{p}=0.013)$ and at the basophil level $(\mathrm{Rs}=0.65$; $\mathrm{p}<0.001)$.

\section{Conclusions}

Basophil reactivity and sensitivity are associated with severity and threshold of allergic reactions to peanut on DBPCPC. Further studies are needed to define prognostic cut-offs values for BAT to determine severity and thresholds of reactivity in peanut allergic patients.

Published: 30 March 2015

doi:10.1186/2045-7022-5-S3-P25

Cite this article as: Santos et al:: The basophil activation test reflects the severity and the threshold of allergic reactions to peanut - a doubleblind-placebo-controlled peanut challenge study. Clinical and

Translational Allergy 2015 5(Suppl 3):P25.

Submit your next manuscript to BioMed Central and take full advantage of:

- Convenient online submission

- Thorough peer review

- No space constraints or color figure charges

- Immediate publication on acceptance

- Inclusion in PubMed, CAS, Scopus and Google Scholar

- Research which is freely available for redistribution

Submit your manuscript at www.biomedcentral.com/submit C Biomed Central 